\title{
CORRESPONDENCE
}

\section{Granitic liquids: their generation and intrusion}

SIR-I was greatly impressed by the arguments and conclusions presented in a recent paper by Cann (1970) on the upward motion of granitic magma. However, I should like to draw your attention to certain additional aspects of the thesis that the driest products of crustal fusion are those which reach the highest levels. These dry granitic melts are associated with the highest crustal fusion temperatures and we should consider the causes in addition to the consequences of melting over a wide temperature range.

As Cann has suggested, we must accept that the availability of water (and hence $\mathbf{P}_{\mathbf{H}_{2} \mathbf{O}}$ ) during primary melting of crustal materials is highly significant in controlling the degree of melting. In an environment where water is freely available large amounts of melt can be produced near the water saturated solidus of the granite system (Tuttle \& Bowen, 1958). Logically, if only limited amounts of free water are present melting is inhibited to an extent which $I$ have delineated (1970) in $P-T$ space using schematic and experimentally substantiated curves of equal water content for granitic liquids. To form the same amount of melt with less water a higher temperature is required. Hence, a reduction of melt water content conveniently allows us to reach an increased temperature before sufficient liquid collects and the necessary volume, density and viscosity considerations are satisfied for intrusion to occur (Fyfe, 1970). Notice that this type of anatexis implies that the first liquid generated at the solidus is always saturated $\left(P_{\mathrm{H}_{2} \mathrm{O}}=P_{\text {Total }}\right)$ even if water is scarce and only with increasing temperature can the ratio $P_{\mathrm{H}_{2} \mathrm{O}}: \boldsymbol{P}_{\text {Total }}$ progressively fall below unity: water undersaturated melting then causes an increase in the volume of liquid. Since we cannot have an initial ratio less than 1 it is misleading to consider anything but the ultimate anatectic conditions in relation to the curves of equal ratio in Cann's diagram. Therefore, an assessment of the actual water content of the piece of crust we are melting is more pertinent since this variable, taken in relation to the water content requirements of granitic liquids within our $P-T$ regime (Brown, 1970 ), puts the limit on the amount of liquid we can produce at various stages of the melting cycle.

The preceeding arguments rely upon there being trace amounts of free water available as anatexis commences. I emphasise the word 'free' because another more significant form of water occurs within crustal materials, i.e. water which is structurally bonded in hydrated lattices. We recently discussed the significance of those prograde metamorphic reactions which affect 'wet' geosynclinal sediments (Brown \& Fyfe, 1970) and concluded that prior to the onset of anatexis all original water probably becomes locked within such hydrated minerals leaving no free water available for solidus melting. Continued progressive burial of metamorphosed sediments causes higher temperatures to be reached; meanwhile the fusion process is delayed until appropriate dehydration reactions commence coupled with the release of water. As the various common hydrates decompose at different conditions the incipient melting temperature will depend on the mineralogical constitution of the crustal segment. Although continued melting from this point is governed by rules similar to those mentioned earlier, it is significant that crustal material is being melted at temperatures already well in excess of the granite solidus; relatively dry liquids are being produced and there has been no time for any intrusive activity. However, intrusion can now occur at any temperature provided that sufficient liquid accumulates. Thus we have a more plausible mechanism for generating a suitable range of melts which, on collecting, finds various amounts of room for upward movement before hitting the solidus and being forced to crystallise in the manner described by Cann ( $c f$. also Harris, Kennedy \& Scarfe, 1970).

Another aspect of this problem upon which we commented recently (Brown \& Fyfe, 1970) concerns the compositional and time relationships of the different granitic members within orogenic belts. In general we found that truly granitic melts, characterised by the highest $\mathrm{K}_{2} \mathrm{O} / \mathrm{Na}_{2} \mathrm{O}$ ratios, are associated with the lowest temperatures of crustal fusion $\left(700-750^{\circ} \mathrm{C}\right.$.) coupled with the destruction of muscovite. Liquid compositions generated from biotite-bearing assemblages are granodioritic $\left(750-850^{\circ} \mathrm{C}\right.$.) and 
those associated with amphibole breakdown ( $\mathrm{ca} .900^{\circ} \mathrm{C}$.) have affinities to quartz diorites. Using the model suggested by Cann it is now evident that wet granitic liquids should have only limited intrusive capacity whereas relatively dry granodioritic and dioritic materials should form the high level intrusions: in a normal burial cycle we might expect the former to be intruded first. Although suitable chemical and chronological data from orogenic belts are rather scarce at present we can test these ideas in relation to the Sierra Nevada batholith (Bateman \& Dodge, 1970) and the N. Chile and Peruvian coastal batholith (Giletti \& Day, 1968; Farrar et al., 1970). Observations in these regions revealed a progressive decrease in isotopic age and increase in $\mathrm{K}_{2} \mathrm{O}$ away from the continental margin over West-East traverses in the $100-200 \mathrm{~km}$ range, i.e. the granodiorites were intruded before the true granites. Perhaps such chemical trends are predictable since potassium will be enriched in the source rocks away from the continental margin; however, it is significant that the first liquids of the 'granite cycle' are generated at rather high temperatures.

A further important feature of such orogenic belts is that they appear to be situated on leading plate margins where wet oceanic crust disappears beneath the continent. Within a Benioff zone these materials are likely to reach the wet solidus of basalt extremely rapidly, especially since the materials above and below are at higher temperatures. The possible existence of molten, mobile basalt vertically beneath an active plate margin is vital to the upward transfer of heat and water into the lower crust (see Fyfe \& Brown, 1971, for a detailed discussion). Consequently, initial melting within the dry basal cratonic crust (with low ${ }^{87} \mathrm{Sr} /{ }^{86} \mathrm{Sr}$ ratios, $c f$. Cann) could generate primary dioritic and granodioritic melts which, as they ascend, will transfer heat to much higher levels. Lower temperature granitic liquids with little intrusive capacity might then appear. Hence, granitic plutons could result at similar crustal levels to the earlier granodiorites and we must presume from the evidence cited earlier that the focus of activity gradually moves away from the continental margin. Certainly this is plausible if crustal processes are still linked with mechanisms operating deep in the Benioff zone. Obviously a thorough analysis of the sequence of events at continental margins both past and present is required, but the model outlined above appears to fit the presently available data concerning the mobility of intrusive melts with a considerable degree of accuracy.

\section{References}

Bateman, P. C. \& Dodge, F. C. W. 1970. Variations of major chemical constituents across the Central Sierra Nevada batholith. Bull. geol. Soc. Amer. 81, 409-20.

Brown, G. C. 1970. A comment on the role of water in the partial fusion of crustal rocks. Earth and Plan. Sci. Letters 9, 355-8.

Brown, G. C. \& Fyfe, W. S. 1970. The production of granitic melts during ultrametamorphism. Contr. Mineral. Petrol. 28, 310-18.

Cann, J. R. 1970. Upward movement of granitic magma. Geol. Mag. 107, 335-40.

Farrar, E., Clark, A. H., Haynes, S. J., Quirt, G. S., Conn, H. and Zentilli, M. 1970. K-Ar evidence for the post-Palaeozoic migration of granitic intrusion foci in the Andes of Northern Chile. Earth and Plan. Sci. Letters 10, 60-6.

Fyfe, W. S. 1970. Some thoughts on granitic magmas. In Mechanism of Igneous Intrusion (ed. G. Newall \& N. Rast). Geol. J. Spec. Issue 2, 201-16.

Fyfe, W. S. \& Brown, G. C. 1971. Granites past and present. J. Earth Sciences (Leeds) Spec. Issue. (In press).

Giletti, B. J. \& Day, H. W. 1968. Potassium-argon ages of igneous intrusive rocks of Peru. Nature, Lond. 220, 570-1.

Harris, P. G., Kennedy, W. Q. \& Scarfe, C. M. 1970. Volcanism versus plutonismthe effect of chemical composition. In Mechanism of Igneous Intrusion (ed. G. Newall \& N. Rast). Geol. J. Spec. Issue 2, 187-200.

Tuttle, O. F. \& Bowen, N. L. 1958. Origin of granite in the light of experimental studies in the system $\mathrm{NaAlSi}_{3} \mathrm{O}_{8}-\mathrm{KAlSi}_{3} \mathrm{O}_{8}-\mathrm{SiO}_{2}-\mathrm{H}_{2} \mathrm{O}$ : Mem. geol. Soc. Amer. 74.

Department of Geology, The University

G. C. BROWN

Manchester, M13 9PL

31 March 1971 
SIR-I am very grateful to Dr Brown (Brown, 1971) for drawing the attention of your readers to the recent work of Fyfe, Harris, Kennedy, Scarfe and himself on the question of granite magmas. My paper (Cann, 1970) was written two and a half years ago, before I was aware of these newer important investigations, which have superseded my preliminary guesses in almost all particulars and should clearly be used as a basis for any further study.

There is only one point in Dr Brown's letter with which I would like to argue. That is the question of a plate tectonic interpretation of observations on batholiths. In my original paper I carefully kept clear of any interpretation, but since Dr Brown has raised the point, it might be useful to look at it further. We take, as it happens, very different views of processes taking place at plate boundaries. While Dr Brown invokes episodic processes, I feel that it is extremely important to try to fit a continuous model to any observations before moving towards episodic models.

The isotopic and compositional data to which Dr Brown refers can, it seems, be interpreted by such a continuous model if one postulates a process of abrasion at oceancontinent converging plate boundaries. By this process, material would be abraded from the leading edge of the continent by the down-going slab of oceanic material. In the case of South America it is possible to estimate the rate of abrasion from the fact that batholiths on the coast give Jurassic ages, and are about $150 \mathrm{~km}$ seaward from the present line of volcanic activity. This leads to an estimate for the rate of abrasion of about $1 \mathrm{~km} / 10^{6} \mathrm{yr}$, or $1 \mathrm{~mm} / \mathrm{yr}$. Similar rates are consistent with observations on the batholiths in North America. Simultaneously, erosion from the land surface would expose deeper and deeper levels in the batholiths. Thus, on going from the present line of volcanic activity towards the coast, ages of intrusive rocks would increase, and intrusions would be eroded to deeper levels.

Thus the observed correlation between age, position and composition mentioned by Dr Brown can be explained in terms of his own data on a continuous model, if the deeper level granites are more potassium rich, which one would expect them to be if they represent more hydrous magmas trapped at greater depth by their own melting curves.

\section{References}

Brown, G. C. 1971. Granitic liquids: their generation and intrusion. Geol. Mag. (above). Cann, J. R. 1970. Upward movement of granitic magma. Geol. Mag. 107, 335-40.

School of Environmental Sciences

J. R. CANN

University of East Anglia

University Village

Norwich, NOR $88 \mathrm{C}$

13 May 1971 